\title{
Industrial energy efficiency and climate change mitigation
}

\author{
Ernst Worrell • Lenny Bernstein • Joyashree Roy • \\ Lynn Price • Jochen Harnisch
}

Received: 15 June 2008 / Accepted: 7 November 2008 / Published online: 30 November 2008

(C) The Author(s) 2008. This article is published with open access at Springerlink.com

\begin{abstract}
Industry contributes directly and indirectly (through consumed electricity) about $37 \%$ of the global greenhouse gas emissions, of which over $80 \%$ is from energy use. Total energy-related emissions, which were $9.9 \mathrm{GtCO}_{2}$ in 2004 , have grown by $65 \%$ since 1971. Even so, industry has almost continuously improved its energy efficiency over the past decades. In the near future, energy efficiency is potentially the most important and cost-effective means for mitigating greenhouse gas emissions from industry. This paper discusses the potential contribution of industrial energy-efficiency technologies and policies to reduce energy use and greenhouse gas emissions to 2030 .
\end{abstract}

Keywords Greenhouse gas mitigation · Industry · Energy efficiency $\cdot$ Policy $\cdot$ Potentials

E. Worrell $(\bowtie)$

Science, Technology \& Society, Copernicus Institute, ECOFYS/Utrecht University,

Heidelberglaan 23584 CS,

Utrecht, The Netherlands

e-mail: e.worrell@uu.nl

L. Bernstein

L.S. Bernstein and Associates,

LLC. 488 Kimberly Avenue,

Asheville, NC 28804, USA

J. Roy

Jadavpur University,

Kolkata 700032, India

\section{Introduction}

This article is based on chapter 7 of the Working Group III report to the IPCC Fourth Assessment (IPCC 2007) and provides a review of the trends, opportunities, and policy options to reduce greenhouse gas $(\mathrm{GHG})$ emissions from the industrial sector. Industry uses almost $40 \%$ of worldwide energy. It contributes almost $37 \%$ of global GHG emissions. In most countries, $\mathrm{CO}_{2}$ accounts for more than $90 \%$ of $\mathrm{CO}_{2}$-eq $\mathrm{GHG}$ emissions from the industrial sector (Price et al. 2006; US EPA 2006). These $\mathrm{CO}_{2}$ emissions arise from three sources: (1) the use of fossil fuels for energy, either directly by industry for heat and power generation or indirectly in the generation of purchased electricity and steam, (2) non-energy uses of fossil fuels in chemical processing

\footnotetext{
L. Price

Lawrence Berkeley National Laboratory,

1 Cyclotron Road,

Berkeley, CA 94720, USA

J. Harnisch

ECOFYS,

Langrabenstrasse 94,

90443 Nürnberg, Germany

Present address:

J. Harnisch

KfW,

Palmengartenstrasse 5-9,

60325 Frankfurt/Main, Germany
} 
and metal smelting, and (3) non-fossil fuel sources, for example cement and lime manufacture. Industrial processes, primarily chemical manufacturing and metal smelting, also emit other GHGs, including methane $\left(\mathrm{CH}_{4}\right)$, nitrous oxide $\left(\mathrm{N}_{2} \mathrm{O}\right)$, HFCs, CFCs, and PFCs,

The energy intensity of industry has steadily declined in most countries since the oil price shocks of the 1970s. Historically, industrial energy-efficiency improvement rates have typically been around $1 \%$ / year. However, various countries have demonstrated that it is possible to double these rates for extended periods of time (i.e., 10 years or more) through the use of policy mechanisms. Still, large potentials exist to further reduce energy use and GHG emissions in most sectors and economies.

\section{Historic and future trends}

Globally, energy-intensive industries still emit the largest share of industrial GHG emissions (Dasgupta and Roy 2000; IEA 2007, 2008; Sinton and Fridley 2000). Hence, this paper focuses on the key energyintensive industries: iron and steel, chemicals (including fertilizers), petroleum refining, minerals (cement, lime, glass, and ceramics), and pulp and paper. The production of energy-intensive industrial goods has grown dramatically and is expected to continue growing as population and per capita income increase. Since 1970, global annual production of cement increased 336\%; aluminum, 252\%; steel, 95\% (USGS 2005); ammonia, 353\% (IFA 2005); and paper, 190\% (FAO 2008). Much of the world's energy-intensive industry is now located in developing nations (see Fig. 1). In 2006, developing countries accounted for $74 \%$ of global cement manufacture (USGS 2005), 63\% of global nitrogen fertilizer production, about $50 \%$ of global primary aluminum production (USGS 2008), and $48 \%$ of global steel production (USGS 2008).

In 2006, developing countries accounted for $49 \%$ of final energy use by industry, developed countries $40 \%$, and economies in transition $11 \%$. Since many facilities in developing nations are new, they sometimes incorporate the latest technology and have the lowest specific emission rates (BEE 2006; IEA 2006b). Many older, inefficient facilities remain in both industrialised and developing countries. However, there is a huge demand for technology transfer (hardware, software, and know-how) to developing nations to achieve energy efficiency and emissions reduction in their industrial sectors. Though largescale production dominates these energy-intensive
Fig. 1 The 1990 and 2006 share of commodities production from OECD, EIT, and non-OECD countries. Source: IFA (2005), UN (2007), USGS (2007), IEA (2008), and FAO (2008)

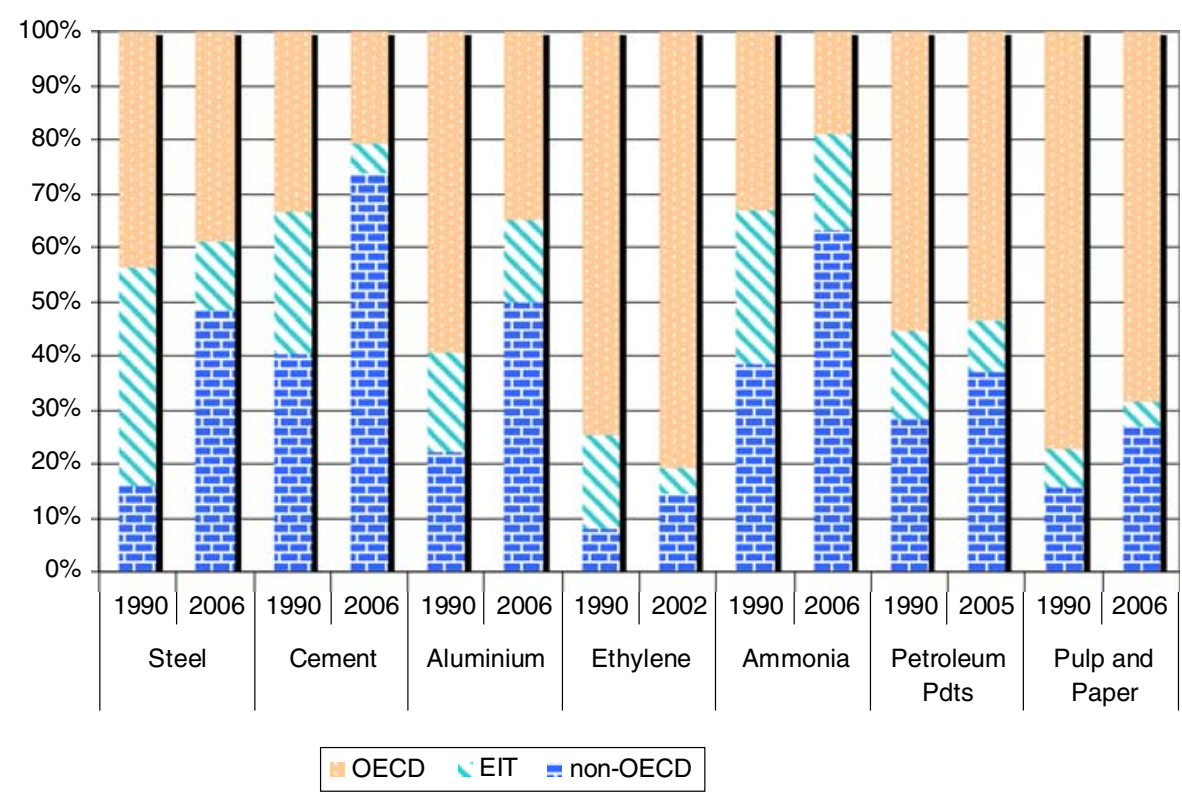

Source: IFA, 2005; UN, 2007; USGS, 2007, IEA, 2008, FAO, 2008. 
industries, globally small- and medium-sized enterprises have significant shares in many developing countries, which create special challenges for mitigation efforts.

Total industrial sector GHG emissions are currently estimated to be about $12 \mathrm{GtCO}_{2}$-eq/year. Global and sectoral data on final energy use, primary energy use, and energy-related $\mathrm{CO}_{2}$ emissions, including indirect emissions related to electricity use, for 1971 to 2005 are shown in Table 1. In 1971, the industrial sector used 91 EJ of primary energy, $40 \%$ of the global total of 227 EJ. By 2005, industry's share of global primary energy use declined to $38 \%$.

Energy use represents the largest source of GHG emissions in industry (83\%). In 2005, energy use by the industrial sector resulted in emissions of $10.2 \mathrm{GtCO}_{2}$, $38 \%$ of global $\mathrm{CO}_{2}$ emissions from energy use. Direct $\mathrm{CO}_{2}$ emissions totalled $5.2 \mathrm{Gt}$, the balance being indirect emissions associated with the generation of electricity and other energy carriers. The developing nations' share of industrial $\mathrm{CO}_{2}$ emissions from energy use grew from $18 \%$ in 1971 to $55 \%$ in 2005 . In 2000 , $\mathrm{CO}_{2}$ emissions from non-energy uses of fossil fuels (e.g., production of petrochemicals) and from nonfossil fuel sources (e.g., cement manufacture) were estimated to be $1.7 \mathrm{GtCO}_{2}$ (Olivier and Peters 2005). Industrial emissions of non- $\mathrm{CO}_{2}$ gases totaled about $0.4 \mathrm{GtCO}_{2}$-eq in 2000 and are projected to be at about the same level in 2010. Direct GHG emissions from the industrial sector are currently about $7.3 \mathrm{GtCO}_{2}$-eq, and total emissions, including indirect emissions, are about $12.3 \mathrm{GtCO}_{2}$-eq.

Future projections of the IPCC (IPCC 2000) show energy-related industrial $\mathrm{CO}_{2}$ emissions of 14 and $20 \mathrm{GtCO}_{2}$ in 2030 for the $\mathrm{B} 2$ and $\mathrm{A} 1 \mathrm{~B}$ scenarios ${ }^{1}$, respectively. In both scenarios, $\mathrm{CO}_{2}$ emissions from industrial energy use are expected to grow significantly in the developing countries while remaining essentially constant in the A1 scenario and declining

\footnotetext{
${ }^{1}$ The terms refer to the IPCC Special report on Emission Scenarios and denote two different world views. The A1-family of scenarios assumes a world of rapid economic growth and regional convergence, with global population peaking midcentury. The B2 scenario reflects a world with modest economic and population growth, while the economies are more locally oriented. Neither scenario is considered more or less probably than the other.
}

in the B2 scenario for the industrialized countries and countries with economies-in-transition.

\section{Energy efficiency and GHG emission mitigation}

IEA (2005) found, "The energy intensity of most industrial processes is at least $50 \%$ higher than the theoretical minimum." This provides a significant opportunity for reducing energy use and its associated $\mathrm{CO}_{2}$ emissions. A wide range of technologies have the potential for reducing industrial GHG emissions, of which energy efficiency is one of the most important, especially in the short- to mid-term. Other opportunities include fuel switching, material efficiency, renewables, and reduction of non- $\mathrm{CO}_{2} \mathrm{GHG}$ emissions. Within each category, some technologies such as the use of more efficient motor systems are broadly applicable across all industries, while others are process specific. Below, we discuss cross-cutting and industry-wide technology opportunities, process or sector-specific technologies, as well as management or operational opportunities.

\section{Sector-wide technologies}

Approximately $65 \%$ of electricity consumed by industry is used by motor systems (De Keulenaer et al. 2004; Xenergy 1998). The efficiency of motordriven systems can be increased by reducing losses in the motor windings, using better magnetic steel, improving the aerodynamics of the motor, and improving manufacturing tolerances. However, maximizing efficiency requires properly sizing of all components, improving the efficiency of the end-use devices (pumps, fans, etc.), reducing electrical and mechanical transmission losses, and the use of proper operation and maintenance procedures. Implementing high-efficiency motor-driven systems or improving existing ones in the EU-25 could save about $30 \%$ of the energy consumption of up to $202 \mathrm{TWh} /$ year (De Keulenaer et al. 2004) and over $100 \mathrm{TWh} /$ year by 2010 in the USA (Xenergy 1998).

IEA (2006a) estimates that steam generation consumes about $15 \%$ of global final industrial energy use. The efficiency of current steam boilers can be as high as $85 \%$, through general maintenance, improved insulation, combustion controls, and leak repair improved steam traps and condensate recovery. 
Table 1 Industrial sector final energy, primary energy, and energy-related carbon dioxide emissions, nine world regions, 1971-2005

\begin{tabular}{|c|c|c|c|c|c|c|c|c|c|}
\hline & \multicolumn{3}{|c|}{ Final energy (EJ) } & \multicolumn{3}{|c|}{ Primary energy (EJ) } & \multicolumn{3}{|c|}{$\begin{array}{l}\text { Energy-related carbon dioxide, including indirect } \\
\text { emissions from electricity use }\left(\mathrm{MtCO}_{2}\right)\end{array}$} \\
\hline & 1971 & 1990 & 2005 & 1971 & 1990 & 2005 & 1971 & 1990 & 2005 \\
\hline Pacific OECD & 6.02 & 8.04 & 10.09 & 8.29 & 11.47 & 14.29 & 524 & 710 & 821 \\
\hline North America & 20.21 & 19.15 & 21.89 & 25.88 & 26.04 & 28.06 & 1,512 & 1,472 & 1461 \\
\hline Western Europe & 14.78 & 14.88 & 16.69 & 19.57 & 20.06 & 21.83 & 1,380 & 1,187 & 1144 \\
\hline Central and East Europe & 3.75 & 4.52 & 2.80 & 5.46 & 7.04 & 3.85 & 424 & 529 & 246 \\
\hline Former Soviet Union & 11.23 & 18.59 & 10.81 & 15.67 & 24.63 & 15.00 & 1,095 & 1,631 & 873 \\
\hline Developing Asia & 7.34 & 19.88 & 37.88 & 9.38 & 26.61 & 60.47 & 714 & 2,012 & 4505 \\
\hline Latin America & 2.79 & 5.94 & 8.39 & 3.58 & 7.53 & 11.16 & 178 & 327 & 480 \\
\hline Sub-Saharan Africa & 1.24 & 2.11 & 2.44 & 1.7 & 2.98 & 3.56 & 98 & 178 & 203 \\
\hline Middle East and North Africa & 0.83 & 4.01 & 6.72 & 1.08 & 4.89 & 8.65 & 65 & 277 & 468 \\
\hline World & 68.18 & 97.13 & 117.71 & 90.61 & 131.25 & 166.86 & 5,990 & 8,324 & 10,199 \\
\hline
\end{tabular}

Biomass energy included. Industrial sector "final energy" use excludes energy consumed in refineries and other energy conversion operations, power plants, coal transformation plants, etc. (IEA 2007, 2008). However, this energy is included in "primary energy". Upstream energy consumption was reallocated by weighting electricity, petroleum, and coal products consumption, with primary factors reflecting energy use and loses in energy industries. Final energy includes feedstock energy consumed, for example in the chemical industry. " $\mathrm{CO}_{2}$ emission" in this table are higher than in IEA's Manufacturing Industries and Construction category because they include upstream $\mathrm{CO}_{2}$ emissions allocated to the consumption of secondary energy products such as electricity and petroleum fuels. To reallocate upstream $\mathrm{CO}_{2}$ emissions to final energy consumption, we calculate $\mathrm{CO}_{2}$ emission factors, which are multiplied by the sector's use of secondary energy (De la Rue du Can and Price 2008)

Studies in the USA identified energy-efficiency opportunities with economically attractive potentials of up to 18-20\% (Einstein et al. 2001; US DOE 2002).

Energy recovery techniques are old, but large potentials still exist (Bergmeier 2003). It can take different forms: heat, power, and fuel recovery. The discarded heat can be re-used in other processes onsite or used to preheat incoming water and combustion air. New, more efficient heat exchangers or more robust (e.g., low-corrosion) heat exchangers are being developed continuously, improving the profitability of enhanced heat recovery. Waste heat conversion by heat transformers or by thermoelectrical conversion as well as recovery of brake energy by power electronics to electricity poses great potential. Typically, cost-effective energy savings of 5\% to $40 \%$ are found in process integration analyses in almost all industries (Worrell et al. 2002; IEA-IETS n.d.).

Power can be recovered from processes operating at elevated pressures using even small pressure differences to produce electricity through pressure recovery turbines. Examples of pressure recovery opportunities are blast furnaces, fluid catalytic crackers, and natural gas grids. Power recovery may also include the use of pressure recovery turbines instead of pressure relief valves in steam networks and organic Rankine cycles from low-temperature waste streams. Bailey and Worrell (2005) found a potential savings of $1 \%$ to $2 \%$ of all power consumed in the USA, which would mitigate $21 \mathrm{MtCO}_{2}$.

Cogeneration (also called combined heat and power, CHP) involves using energy losses in power production to generate heat and/or cold for industrial processes and district heating, providing significantly higher system efficiencies. Industrial cogeneration is an important part of power generation in Germany and the Netherlands and in many countries. Mitigation potential for industrial cogeneration is estimated at almost $150 \mathrm{MtCO}_{2}$ for the USA (Lemar 2001) and $334 \mathrm{MtCO}_{2}$ for Europe (De Beer et al. 2001).

Inter-industry energy-efficiency opportunities

Use of granulated slag in Portland cement may increase energy use in the steel industry, but can reduce both energy consumption and $\mathrm{CO}_{2}$ emissions during cement production by about $40 \%$ (Cornish and Kerkhoff 2004). Co-siting of industries can achieve GHG mitigation by allowing the use of byproducts as useful input and by integrating energy systems. In 
Kalundborg (Denmark), various industries (e.g., cement and pharmaceuticals production and a CHP plant) form an eco-industrial park that serves as an example of the integration of energy and material flows (Heeres et al. 2004). Heat-cascading systems, where waste heat from one industry is used by another, are a promising cross-industry option for saving energy. Based on the Second Law of Thermodynamics, Grothcurth et al. (1989) estimated up to $60 \%$ theoretical energy-saving potential from heat cascading systems. However, as the potential is dependent on many site-specific factors, the practical potential of these systems may be limited to approximately 5\% (Matsuhashi et al. 2000). Other examples are the use of (waste) fuels generated by one industry and used by another industry, while this results in GHG emission reductions, this may not result in energy-efficiency improvement.

\section{Process-specific technologies and measures}

This section discusses process-specific mitigation options, focusing on energy-intensive industries: iron and steel, chemicals, petroleum refining, minerals (cement, lime, and glass), and pulp and paper. These industries (excluding petroleum refining) accounted for almost $70 \%$ of industrial final energy use in 2003 (IEA 2006a). With petroleum refining, the total is over $80 \%$. All the industries discussed in this section can also benefit from application of the technologies and measures described above.

Iron and steel Global steel industry with production of $1,129 \mathrm{Mt}$ in 2005 emits 2,200 to $2,500 \mathrm{MtCO}_{2}$ or about $6 \%$ to $7 \%$ of global anthropogenic emissions (Kim and Worrell 2002a), including emissions from coke manufacture and indirect emissions due to power consumption. Emissions per tonne of steel vary widely between countries: $1.25 \mathrm{tCO}_{2}$ in Brazil, $1.6 \mathrm{tCO}_{2}$ in Korea and Mexico, $2.0 \mathrm{tCO}_{2}$ in the USA, and 3.1 to $3.8 \mathrm{tCO}_{2}$ in China and India (Kim and Worrell 2002a). These differences are due to a range of factors, including fuel mix, different degrees of integration but mainly due to the age and type of technology, and levels of retrofitting of energyrelevant process steps.

Iron and steel production is a combination of batch processes. Steel industry efforts to improve energy efficiency include enhancing continuous production processes to reduce heat loss, increasing recovery of waste energy and process gases, and efficient design of electric arc furnaces, for example, scrap preheating, high-capacity furnaces, foamy slagging, and fuel and oxygen injection. The potential for energy-efficiency improvement varies based on the production route used, product mix, energy and carbon intensities of fuel and electricity, and the boundaries chosen for the evaluation. Kim and Worrell (2002a) estimated socioeconomic potential by taking industry structure into account. They benchmarked the energy efficiency of steel production to the best practice performance in five countries with over $50 \%$ of world steel production, finding potential $\mathrm{CO}_{2}$ emission reductions due to energy-efficiency improvement varying from $15 \%$ (Japan) to $40 \%$ (China, India, and the USA). A study in 2000 estimated the 2010 global technical potential for energy-efficiency improvement with existing technologies at 24\% (De Beer et al. 2000a) and that an additional 5\% could be achieved by 2020 using advanced technologies such as smelt reduction and near net shape casting. Economics may limit the achievable emission reduction potential. A recent analysis of the efficiency improvement of electric arc furnaces in the US steel industry found that the average efficiency improvement between 1990 and 2002 was $1.3 \%$ /year, of which $0.7 \%$ was due to stock turnover and $0.5 \%$ due to retrofit of existing furnaces (Worrell and Biermans 2005).

Chemicals and fertilizers The chemical industry is highly diverse, with thousands of companies producing tens of thousands of products in quantities varying from a few kilograms to thousand of tonnes. Worrell and Galitsky (2004) identify separations, chemical synthesis, and process heating as the major energy consumers in the chemical industry and list examples of technology advances that could reduce energy consumption in each area, for example, improved membranes for separations, more selective catalysts for synthesis, and greater process integration to reduce process heating requirements. Longer-term, biological processing offers the potential of lower energy routes to chemical products.

Ethylene, which is used in the production of plastics and many other products, is produced by steam cracking hydrocarbon feedstocks, from ethane to gas oil. Hydrogen, methane, propylene, and heavier 
hydrocarbons are produced as byproducts. The heavier the feedstock, the more and heavier the byproducts, and the more energy consumed per tonne of ethylene produced. Ren et al. (2006) report that steam cracking for olefin production is the most energy-consuming process in the chemicals industry, accounting for emissions of about $180 \mathrm{MtCO}_{2}$ year and that significant reductions are possible. Cracking consumes about $65 \%$ of the total energy used in ethylene production, but use of state-of-the-art technologies (e.g., improved furnace and cracking tube materials and cogeneration using furnace exhaust) could save up to about $20 \%$ of total energy. The remainder of the energy is used for separation of the ethylene product, typically by low-temperature distillation and compression. Up to $15 \%$ total energy can be saved by improved separation and compression techniques (e.g., absorption technologies for separation).

Swaminathan and Sukalac (2004) report that the fertilizer industry uses about $1.2 \%$ of world energy consumption. More than $90 \%$ of this energy is used in the production of ammonia $\left(\mathrm{NH}_{3}\right)$. However, as the result of energy-efficiency improvements, modern ammonia plants are designed to use about half the energy per tonne of product than those designed in 1960 s, with design energy consumption dropping from over $60 \mathrm{GJ} / \mathrm{t} \mathrm{NH}$ in the 1960 s to $28 \mathrm{GJ} / \mathrm{t} \mathrm{NH}_{3}$ in the latest design plants, approaching the thermodynamic limit of about $19 \mathrm{GJ} / \mathrm{t} \mathrm{NH}_{3}$. Benchmarking data indicate that the best-in-class performance of operating plants ranges from 28.0 to $29.3 \mathrm{GJ} / \mathrm{t} \mathrm{NH}_{3}$ (Chaudhary 2001; PSI 2004). The newest plants tend to have the best energy performance, and many of them are located in developing countries, which now account for $63 \%$ of nitrogen fertilizer production (USGS 2007). Individual differences in energy performance are mostly determined by feedstock (natural gas compared with heavier hydrocarbons) and the age and size of the ammonia plant (PSI 2004; Phylipsen et al. 2002).

Petroleum refining As of the beginning of 2004, there were 735 refineries in 128 countries, with a total crude oil distillation capacity of 82.3 million barrels per day. Petroleum industry operations consume up to $15 \%$ to $20 \%$ of the energy in crude oil or $5 \%$ to $7 \%$ of world primary energy, with refineries consuming most of that energy (Eidt 2004). Worrell and Galitsky (2005), based on a survey of US refinery operations, found that most petroleum refineries can economical- ly improve energy efficiency by $10-20 \%$ and provided a list of over 100 potential energy-saving steps. The petroleum industry has had long-standing energyefficiency programs for refineries and the chemical plants with which they are often integrated. These efforts have yielded significant results. Exxon Mobil reported over 35\% reduction in energy use in its refineries and chemical plants from 1974 to 1999 and in 2000 instituted a program whose goal was a further $15 \%$ reduction. Chevron reported a $24 \%$ reduction in its index of energy use between 1992 and 2004.

Cement Global cement production grew from $594 \mathrm{Mt}$ in 1970 to 2,550 Mt in 2006. In 2006, developed countries produced $529 \mathrm{Mt}$ ( $21 \%$ of world production) and developing countries 1,886 Mt (74\%) (USGS 2005). The production of clinker emits $\mathrm{CO}_{2}$ from the calcination of limestone. The major energy uses are fuel for the production of clinker and electricity for grinding raw materials and the finished cement. Based on average emission intensities, total emissions in 2005 are estimated at 1,800 to $2,000 \mathrm{MtCO}_{2}$ or about $7 \%$ of global $\mathrm{CO}_{2}$ emissions, half from process emissions, $40 \%$ from direct energy use, and 10\% from used electricity. Global average $\mathrm{CO}_{2}$ emission per tonne cement production is estimated by Worrell et al. (2001) at $814 \mathrm{~kg}$. $\mathrm{CO}_{2}$ emission/t cement vary by region from a low of $700 \mathrm{~kg}$ in Western Europe and $730 \mathrm{~kg}$ in Japan and South Korea to a high of 900, 930, and $935 \mathrm{~kg}$ in China, India, and the United States (Humphreys and Mahasenan 2002; Worrell et al. 2001). This reflects differences of fuels mixes, cement types, and also kiln technologies, with age and size being critical parameters.

Emission intensities have decreased by approximately 0.9\%/year since 1990 in Canada, 0.3\%/year (1970-1999) in the USA, and 1\%/year in Mexico (Nyboer and Tu 2003; Worrell and Galitsky 2004; Sheinbaum and Ozawa 1998). Benchmarking and other studies have demonstrated a technical potential for up to $40 \%$ improvement in energy efficiency (Kim and Worrell 2002b; Worrell et al. 1995). Countries with a high potential still use outdated technologies, like the wet process clinker kiln.

Pulp and paper Direct emissions from the pulp, paper, paperboard, and wood products industries are estimated to be $264 \mathrm{MtCO}_{2} /$ year (Miner and Lucier 2004). The industry's indirect emissions from pur- 
chased electricity are less certain, but are estimated to be 130 to $180 \mathrm{MtCO}_{2} /$ year (WBCSD 2005). Mitigation opportunities in the pulp and paper industry consist of energy-efficiency improvement, cogeneration, increased use of (self-generated) biomass fuel, and increased recycling of recovered paper. As the pulp and paper industry consumes large amounts of motive power and steam, the cross-cutting measures discussed above apply to this industry.

Because of increased use of biomass and energyefficiency improvements, the GHG emissions from the pulp and paper industry have been reduced over time. Since $1990, \mathrm{CO}_{2}$ emission intensity of the European paper industry has decreased by approximately $25 \%$ (WBCSD 2005), the Australian pulp and paper industry about 20\% (A3P 2006), and the Canadian pulp and paper industry over $40 \%$ (FPAC n.d.). Fossil fuel use by the US pulp and paper industry declined by more than $50 \%$ between 1972 and 2002 (AF\&PA 2004). However, despite these improvements, Martin et al. (2000) found a technical potential for GHG reduction of $25 \%$ and a cost-effective potential of $14 \%$ through widespread adoption of 45 energysaving technologies and measures in the US pulp and paper industry. Inter-country comparisons of energy intensity in the mid-1990s suggest that fuel consumption by the pulp and paper industry could be reduced by $20 \%$ or more in a number of countries by adopting best practices (Farla et al. 1997).

\section{Management and operations}

Management tools can reduce energy use. Staff training in companies' general approach to energyefficiency (Caffal 1995) reward systems has had good results. Several countries have instituted voluntary corporate energy management standards (e.g., Canada, Denmark, Ireland, Sweden, and the USA). Companies of all sizes use energy audits to identify opportunities for reducing energy use. Approximately $10 \%$ (Okazaki et al. 2004) of total energy consumption in steel making could be saved through improved energy and materials management.

Companies can use benchmarking to compare their operations with those of others, to industry average or to best practice, to improve energy efficiency. The petroleum industry has the longest experience with energy-efficiency benchmarking through the use of an industry-accepted index developed by a private company (Barats 2005). Many benchmarking programs are developed through trade associations or ad hoc consortia of companies, and their details are often proprietary. However, ten Canadian potash operations published the details of their benchmarking exercise (CFI 2003), which showed that increased employee awareness and training was the most frequently identified opportunity for improved energy performance. Several governments have supported the development of benchmarking programs in various forms, for example Canada, Flanders (Belgium), the Netherlands, Norway, and the USA.

Application of housekeeping and general maintenance on older, less-efficient plants can yield energy savings of $10-20 \%$. Low-cost/minor capital measures (e.g., combustion efficiency optimization, recovery and use of exhaust gases, use of correctly sized, highefficiency electric motors, and insulation) show energy savings of $20-30 \%$. Higher capital expenditure measures (e.g., automatic combustion control, improved design features for optimization of piping sizing and air intake sizing, and use of variable speed drive motors, automatic load control systems, and process residuals) can result in energy savings of 4050\% (UNIDO 2001; Bakaya-Kyahurwa 2004).

\section{Medium-term mitigation potential and cost}

An attempt to estimate global mitigation potential from national and regional estimates was unsuccessful. Information is lacking for the former Soviet Union, Africa, Latin America, and parts of Asia. However, we were able to develop a global estimate for the industrial sector by summing estimates of the mitigation potential in specific industry sub-sectors, e.g., iron and steel. Table 2 presents an estimate of the industrial sector mitigation potential and cost in 2030 .

Mitigation potential and cost for industrial $\mathrm{CO}_{2}$ emissions were estimated as follows:

1. Price et al. (2006) estimates for 2030 production rate by industry and geographic area for the SRES A1 and B2 scenarios (IPCC 2000) were used.

2. Mitigation potential estimates available from literature have been supplemented by mitigation potential estimates developed by assuming deployment of current best practice by all plants in 2030 . 
Mitigation cost estimates are based on both published values and expert judgment. In most cases, the available cost information was not comprehensive, and we have not developed marginal abatement cost curves. Estimates have not been made for some smaller industries (e.g., glass) and for the light industries. A significant amount of information was available on industrial sector mitigation potential and cost by country or region. To build up a truly global estimate from this data was not possible at the time as robust information was lacking for the former Soviet Union, Africa, Latin America, and parts of Asia.
Table 2 is based on a limited number of studies and implicitly assumes that current trends will continue until 2030. Key uncertainties in the projections include the rate of technology development and diffusion, the cost of future technology, future energy and carbon prices, the level of industrial activity in 2030, and policy driver, both climate and non-climate. The use of two scenarios, A1B and B2, helps in estimation of range of values to reflect uncertainties.

About a third of the savings potential of electric motor systems (see above) was assumed to be realized in the baseline, resulting in a net mitigation potential of $13 \%$ of industrial electricity use. This mitigation

Table 2 Estimated potential for $\mathrm{CO}_{2}$ emission reduction in 2030

\begin{tabular}{|c|c|c|c|c|c|c|c|}
\hline & \multirow[t]{2}{*}{ Area $^{a}$} & \multicolumn{2}{|c|}{2030 production $(\mathrm{Mt})^{\mathrm{b}}$} & \multirow{2}{*}{$\begin{array}{l}\text { Mitigation } \\
\text { potential (\%) }\end{array}$} & \multirow{2}{*}{$\begin{array}{l}\text { Cost range, } \\
\left(\$ / \mathrm{tCO}_{2}-\mathrm{eq}\right)\end{array}$} & \multicolumn{2}{|c|}{ Mitigation potential $\left(\mathrm{MtCO}_{2}\right.$-eq/year) } \\
\hline & & A1 & $\mathrm{B} 2$ & & & A1 & B2 \\
\hline \multicolumn{8}{|c|}{$\mathrm{CO}_{2}$ emissions from processes and energy use } \\
\hline \multirow[t]{4}{*}{ Steel $^{\mathrm{c}, \mathrm{d}}$} & Global & 1,554 & 1,578 & $15-40$ & $<50$ & $430-1,500$ & $420-1,500$ \\
\hline & OECD & 436 & 388 & $15-40$ & $<50$ & $90-300$ & $80-260$ \\
\hline & EIT & 176 & 193 & $25-40$ & $<50$ & $80-240$ & $85-260$ \\
\hline & Dev. Nat. & 941 & 997 & $25-40$ & $<50$ & $260-970$ & $250-940$ \\
\hline \multirow[t]{4}{*}{ Primary aluminum ${ }^{\mathrm{e} f \mathrm{f}}$} & Global & 49 & 43 & $15-25$ & $<100$ & $53-82$ & $49-75$ \\
\hline & OECD & 12 & 12 & $15-25$ & $<100$ & $16-25$ & $15-22$ \\
\hline & EIT & 6 & 6 & $15-25$ & $<100$ & $12-19$ & $8-13$ \\
\hline & Dev. Nat. & 31 & 25 & $15-25$ & $<100$ & $25-38$ & $26-40$ \\
\hline \multirow[t]{4}{*}{ Cement $^{\mathrm{g}, \mathrm{h}, \mathrm{i}}$} & Global & 5,524 & 4,418 & $11-40$ & $<50$ & $720-2,100$ & $480-1,700$ \\
\hline & OECD & 596 & 553 & $11-40$ & $<50$ & $65-180$ & $50-160$ \\
\hline & EIT & 313 & 219 & $11-40$ & $<50$ & $40-120$ & $20-60$ \\
\hline & Dev. Nat. & 4,615 & 3,645 & $11-40$ & $<50$ & $610-1,800$ & $410-1,500$ \\
\hline \multirow[t]{4}{*}{ Ethylene $^{\mathrm{j}}$} & Global & 329 & 218 & 20 & $<20$ & 85 & 58 \\
\hline & OECD & 138 & 147 & 20 & $<20$ & 35 & 40 \\
\hline & EIT & 19 & 11 & 20 & $<20$ & 5 & 3 \\
\hline & Dev. Nat. & 171 & 60 & 20 & $<20$ & 45 & 15 \\
\hline \multirow[t]{4}{*}{ Ammonia $^{\mathrm{k}, 1}$} & Global & 199 & 195 & 25 & $<20$ & 110 & 100 \\
\hline & OECD & 20 & 18 & 25 & $<20$ & 11 & 10 \\
\hline & EIT & 19 & 22 & 25 & $<20$ & 10 & 12 \\
\hline & Dev. Nat. & 159 & 155 & 25 & $<20$ & 87 & 80 \\
\hline \multirow[t]{4}{*}{ Petroleum refining $^{\mathrm{m}}$} & Global & 4,838 & 4,697 & $10-20$ & Half $<20$ & $150-300$ & $140-280$ \\
\hline & OECD & 2,220 & 2,123 & $10-20$ & Half $<50$ & $70-140$ & $67-130$ \\
\hline & EIT & 412 & 415 & $10-20$ & Half $<50$ & $12-24$ & $12-24$ \\
\hline & Dev. Nat. & 2,206 & 2,160 & $10-20$ & Half $<50$ & $68-140$ & $65-130$ \\
\hline \multirow[t]{4}{*}{ Pulp and paper ${ }^{\mathrm{n}}$} & Global & 1,226 & 927 & $5-40$ & $<20$ & $49-420$ & $37-300$ \\
\hline & OECD & 657 & 536 & $5-40$ & $<20$ & $28-220$ & $22-180$ \\
\hline & EIT & 62 & 42 & $5-40$ & $<20$ & $3-21$ & $2-13$ \\
\hline & Dev. Nat. & 508 & 349 & $5-40$ & $<20$ & $18-180$ & $13-110$ \\
\hline \multicolumn{8}{|c|}{ Other industries, electricity conservation } \\
\hline & Global & & & & $25 \%<20$ & $1,100-1,300$ & $410-540$ \\
\hline & OECD & & & & $25 \%<50$ & $140-210$ & $65-140$ \\
\hline & EIT & & & & $50 \%<100$ & $340-350$ & $71-85$ \\
\hline & Dev. Nat. & & & & $-\mathrm{d}$ & $640-700$ & $280-320$ \\
\hline
\end{tabular}


Table 2 (continued)

\begin{tabular}{|c|c|c|c|c|}
\hline Area $^{a}$ & 2030 production $(\mathrm{Mt})^{\mathrm{b}}$ & Mitigation & Cost range, & Mitigation potential $\left(\mathrm{MtCO}_{2}\right.$-eq/year) \\
\hline & $\mathrm{A} 1 \quad \mathrm{~B} 2$ & potential $(\%)$ & $\left(\$ / \mathrm{tCO}_{2}-\mathrm{eq}\right)$ & A1 $\quad$ B2 \\
\hline
\end{tabular}

Total

$\begin{array}{llll}\text { Sum }^{\text {o,p,q }} & \text { Global } & 2,300-7,500 & 1,500-6,100 \\ & \text { OECD } & 400-1500 & 300-1,300 \\ & \text { EIT } & 500-900 & 200-600 \\ & \text { Dev. Nat. } & 1,500-4,600 & 1,000-3,800\end{array}$

Results are presented for selected energy-intensive industries and for three world regions. Impact of increased recycling is included in the potentials as (material) efficiency improvement. Note that it was impossible to distinguish fuel mix effects from efficiency changes. However, fuel mix effects are generally very small, except for the cement and pulp and paper industries

${ }^{\text {a }}$ Global total may not equal sum of regions due to independent rounding

${ }^{\mathrm{b}}$ Price et al. 2006

${ }^{\mathrm{c}}$ Kim and Worrell 2002a

${ }^{\mathrm{d}}$ Expert judgment

${ }^{\mathrm{e}}$ Emission intensity based on IAI Life-Cycle Analysis, excluding alumina production and aluminum shaping and rolling. Emissions include anode manufacture, anode oxidation, and power and fuel used in the primary smelter, but exclude PFC emission reduction

${ }^{\mathrm{f}}$ Assumes upgrade to current state-of-the art smelter electricity use and 50\% penetration of zero emission inert electrode technology by 2030

${ }^{g}$ Humphreys and Mahasenan 2002

${ }^{\mathrm{h}}$ Hendriks et al. 1999

${ }^{\mathrm{i}}$ Worrell et al. 1995

${ }^{\mathrm{j}}$ Ren et al. 2005

${ }^{\mathrm{k}}$ Basis for estimate: $10 \mathrm{GJ} \mathrm{t}^{-1} \mathrm{NH}_{3}$ difference between the average plant and the best available technology and operation on natural gas

${ }^{1}$ Rafiqul et al. 2005

${ }^{\mathrm{m}}$ Worrell and Galitsky 2005

${ }^{\mathrm{n}}$ Farahani et al. 2004

${ }^{o}$ Due to gaps in quantitative information, the column sums in this table do not represent total industry emissions or mitigation potential. Global total may not equal sum of regions due to independent rounding

$\mathrm{p}$ The mitigation potential of the main industries include electricity savings

${ }^{\mathrm{q}}$ Mitigation potential for other industries includes only reductions for reduced electricity use for motors. Limited data in the literature did not allow estimation of the potential for other mitigation options in these industries

potential was included in the estimates of mitigation potential for energy-intensive industries presented in Table 2.

However, it is also necessary to consider the potential for electricity savings from non-energyintensive industries, which are large consumers of electricity. Due to data limitations, US data (EIA 2005) on electricity use as a fraction of total energy use by industry and on the fraction of electricity use consumed by motor-driven systems were taken as representative of global patterns. The emission reduction potential from motor systems in the non-energyintensive industries have been estimated as residual by subtracting the savings from energy-intensive industries from total industrial emissions reduction potential.
The total potential for GHG emission mitigation in the industrial sector by 2030 is estimated to be $10-33 \%$ of the A1B SRES scenario and $9-37 \%$ in the B1 SRES scenario.

\section{Lessons learned and policy implications}

Industry can respond to the potential for increased government regulation or changes in consumer preferences in two ways: by mitigating its own GHG emissions and by developing new, lower GHG emission products and services. To the extent that industry does this before being required by either regulation or the market, it is demonstrating the type of anticipatory or planned adaptation. Due to the 
variety of barriers faced by industrial decision makers, there is no "silver bullet", i.e., no single policy to resolve the barriers for all industries. We discuss in next sections a portfolio of policies that have been tried in various countries.

Voluntary programs and agreements

Voluntary agreements are defined as formal agreements that are essentially contracts between government and industry that include negotiated targets with time schedules and commitments on the part of all participating parties (IEA 1997). Voluntary agreements by industry have been implemented in industrialized countries since the early 1990s. These agreements fall into three categories: completely voluntary, voluntary with the threat of future taxes or regulation if shown to be ineffective, and voluntary, but associated with an energy or carbon tax (Price 2005). Agreements that include explicit targets and exert pressure on industry to meet those targets are the most effective (UNFCCC 2002). Voluntary agreements typically cover a period of 5 to 10 years so that strategic energy-efficiency investments can be planned and implemented.

Independent assessments find that experience with voluntary agreements has been mixed with some of the earlier programs appearing to have been poorly designed, failing to meet targets or only achieving business-as-usual savings (Bossoken 1999; Chidiak 2000, 2002; Hansen and Larsen 1999; OECD 2002; Starzer 2000). Recently, a number of voluntary agreement programs have been modified and strengthened, while additional countries, including some newly industrialized and developing countries, are adopting such agreements in efforts to increase the efficiency of their industrial sectors (Price 2005). The more successful programs are typically those that have either an implicit threat of future taxes or regulations or those that work in conjunction with an energy or carbon tax, such as the Dutch LongTerm Agreements, the Danish Agreement on Industrial Energy Efficiency, and the UK Climate Change Agreements. Such programs can provide energy savings beyond business-as-usual (Bjørner and Jensen 2002; Future Energy Solutions 2004, 2005) and are cost effective (Phylipsen and Blok 2002). The LongTerm Agreements, for example, stimulated between $27 \%$ and $44 \%$ (17 to $28 \mathrm{PJ}$ ) of the observed energy savings, which was a $50 \%$ increase over historical autonomous energy-efficiency rates in the Netherlands prior to the agreements (Kerssemeeckers 2002; Rietbergen et al. 2002).

In addition to the energy and carbon savings, these agreements have important longer-term impacts (Delmas and Terlaak 2000; Dowd et al. 2001), including changing attitudes, reducing barriers to innovation and technology adoption, creating market transformations, promoting positive dynamic interactions between different actors involved in technology research and development, deployment, and market development, and facilitating cooperative arrangements that provide learning mechanisms within an industry.

Financial instruments: taxes, subsidies, and access to capital

To date, there is limited experience with taxing industrial GHG emissions. The UK Climate Change Levy applies to industry only and is levied on all nonhousehold use of coal, gas, electricity, and nontransport LPG. Fuels used for electricity generation or non-energy uses, waste-derived fuels, renewable energy, including quality $\mathrm{CHP}$, which uses specified fuels and meets minimum efficiency standards, are exempted from the tax.

Subsidies are also used to stimulate investment in energy-saving measures by reducing investment cost. Subsidies to the industrial sector include grants, favorable loans, and fiscal incentives such as reduced taxes on energy-efficient equipments, accelerated depreciation, tax credits, and tax deductions. Many developed and developing countries have financial schemes to promote industrial energy savings. Evaluations show that subsidies for industry may lead to energy savings and can create a larger market for energy-efficient technologies (De Beer et al. 2000b; WEC 2001). Whether the benefits to society outweigh the cost of these programs or whether other instruments would have been more cost effective has to be evaluated on a case-by-case basis.

Investors in developing countries tend to have a weak capital base. Development and finance institutions therefore often play a critical role in implementing energy-efficiency policies. Their role often goes beyond the provision of project finance and may directly influence technology choice and the direction of innovation (George and Prabhu 2003). The retreat 
of national development banks in some developing countries (as a result of both financial liberalization and financial crises in national governments) may hinder the widespread adoption of mitigation technologies because of lack of financial mechanisms to handle the associated risk.

\section{Regulation and labeling}

For specific activities and regions, there is scope for reducing greenhouse gas emissions from industrial sectors via regulation. For example, mandating the labeling of mass-produced motor systems or of products containing fluorinated gases is an option, as well as training and certification requirements for technicians or planners or requiring adequate investment profitability calculations based on life cycle costing approaches. The first regulations on non- $\mathrm{CO}_{2}$ GHGs are emerging in Europe. A new EU regulation (EC 842/2006) on fluorinated gases includes prohibition of the use of $\mathrm{SF}_{6}$ in magnesium die casting. The regulation contains a review clause that could lead to further use restrictions. National legislation is in place in Austria, Denmark, Luxembourg, Sweden, and Switzerland that limits the use of HFCs in refrigeration equipment, foams, and solvents. During the review of permits for large installations under the EU's Integrated Pollution Prevention and Control (IPPC) Directive (EC, 96/61), a number of facilities have been required to implement best available control technologies, e.g., for $\mathrm{N}_{2} \mathrm{O}$ and fluorinated gases.

Technology research, development, deployment, and diffusion (RDD\&D)

Most industrial processes use at least 50\% more than the theoretical minimum energy requirement determined by the laws of thermodynamics, suggesting a large potential for energy-efficiency improvement and GHG emission mitigation (IEA 2006a). However, RDD\&D is required to capture these potential efficiency gains and achieve significant GHG emission reductions. It is important to realize that successful technologies must also meet a host of other performance criteria, including cost competitiveness, safety, and regulatory requirements, as well as winning consumer acceptance. A review of 54 emerging energy-efficient technologies, produced or implemented in the US, EU, Japan, and other industrialized countries for the industrial sector, found that 20 of the technologies had environmental benefits in the areas of "reduction of wastes" and "emissions of criteria air pollutants". In addition, 35 of the technologies had productivity or product quality benefits (Worrell et al. 2002). Inclusion of quantified co-benefits in an energy-conservation supply curve for the US iron and steel industry doubled the potential for cost-effective savings (Worrell et al. 2003). In many situations, a range co-benefits result from improving efficiencies at the useful energy level. Long-term efficiency approaches by process substitution relying on major innovations are likely to become increasingly important as existing technology options reach full market penetration.

Industry is not running out of energy-efficient technologies, as new technologies are developed continuously (Worrell et al. 2002). Technology RDD\&D is carried out by both governments (public sector) and companies (private sector). Ideally, the roles of the public and private sectors will be complementary. Flannery (2001) argued that it is appropriate for governments to identify the fundamental barriers to technology and find solutions that improve performance, including environmental, cost and safety performance, and perhaps customer acceptability but that the private sector should bear the risk and capture the rewards of commercializing technology. Studies by Luiten and Blok (2003a, b) have shown that a better understanding of the technology and the development process cultivating "champions" for technology development is essential in the design of effective government support of technology development. In its analysis of its Accelerated Technology scenarios, IEA (2006a), as well as the estimate of the 2030 potential discussed above, found that end-use energy efficiency, much of it in the industrial sector, contributed most to mitigation of $\mathrm{CO}_{2}$ emissions from energy use. It accounted for $39-53 \%$ of the projected reduction. However, IEA countries spent only $17 \%$ of their public energy R\&D budgets on energy efficiency (IEA 2005).

\section{Conclusions}

Industry contributes directly and indirectly about $37 \%$ of the global greenhouse gas emissions. Total energy-related industrial emissions have grown by 65\% since 1971. 
Full use of available mitigation options is not being made in either industrialized or developing nations due to a number of barriers like limited access to capital, lack of management attention, insufficient availability of knowledge, or qualified service providers. Although industry has almost continuously improved its energy efficiency over the past decades, energy efficiency remains the most cost-effective option for GHG mitigation for the next decades. Reduction of non- $\mathrm{CO}_{2}$ GHGs and energy efficiency are the least cost options. It proved to be difficult to estimate the potential for energy-efficiency improvement on a global scale. Only few regional or global studies have been undertaken since the IPCC Third Assessment Report (IPCC 2001). Key uncertainties in the projection of mitigation potential and cost in 2030 are the rate of technology development and diffusion, the cost of future technology, future energy and carbon prices, the level of industry activity in 2030, and policy drivers, both climate and non-climate.

Key gaps in knowledge are baseline energy intensity for specific industries, especially in transition economies, the potential energy-efficiency improvement potential in non-energy-intensive industries, quantification of co-benefits, sustainable development implications of mitigation options, and the impact of consumer preferences. Further research is recommended to improve the knowledge base and improve our understanding of the mechanisms to realize energy-efficiency and greenhouse gas mitigation opportunities in the industrial sector.

Acknowledgments We wish to thank the other lead and contributing authors of the original chapter in the 4th Assessment Report of the IPCC for their contribution to the original chapter on which this article is based. We also would like to thank the review editors of the original chapter, as well as all reviewers that provided comments on earlier versions of the report and the two reviewers, who provided comments on an earlier version of this manuscript.

Open Access This article is distributed under the terms of the Creative Commons Attribution Noncommercial License which permits any noncommercial use, distribution, and reproduction in any medium, provided the original author(s) and source are credited.

\section{References}

AF\&PA. (2004). AF\&PA environmental, health and safety verification program: Year 2002 report. Washington, D.C.: American Forest and Paper Association.
A3P. (2006). Performance, people and prosperity: A3P Sustainability Action Plan. Australian Plantation Products and Paper Industry Council. <http://www.a3p.asn.au/assets/pdf/ PerformancePeopleProsperity_actionplan.pdf $>$, accessed 01/06/07.

Bailey, O., \& Worrell, E. (2005). Clean energy technologies, a preliminary inventory of the potential for electricity generation. Berkeley, California (LBNL-57451): Lawrence Berkeley National Laboratory.

Bakaya-Kyahurwa, E. (2004). Energy efficiency and energy awareness in Botswana; ESI. Power Journal of Africa, 2, 36- 40.

Barats, C. (2005). Managing greenhouse gas risk: A roadmap for moving forward. Presented at Risk and Insurance Management Society Annual Meeting. Philadelphia, PA, April 20, 2005. <www.wbcsd.org/web/publications/ batelle-full.pdf $>$, accessed 31/05/07.

BEE. (2006). Implementation: Case studies from industries. Bureau of Energy Efficiency, $<$ www.bee-india.nic.in/ Implementation/Designated\%20Consumers.htm>, accessed $31 / 05 / 07$.

Bergmeier, M. (2003). The history of waste energy recovery in Germany since 1920. Energy, 28, 1359-1374.

Bjørner, T. B., \& Jensen, H. H. (2002). Energy taxes, voluntary agreements and investment subsidies - A micro panel analysis of the effect on Danish industrial companies' energy demand. Resource and Energy Economics, 24, 229-249.

Bossoken, E. (1999). Case study: A comparison between France and The Netherlands of the Voluntary Agreements Policy. Study carried out in the frame of the MURE project, financed by the SAVE programme, European Commission, Directorate General for Energy (DG 17).

Caffal, C. (1995). Energy management in industry. Centre for the Analysis and Dissemination of Demonstrated Energy Technologies (CADDET). Analysis Series 17. Sittard, The Netherlands.

CFI. (2003). Energy benchmarking: Canadian potash production facilities. Canadian fertilizer institute. Ottawa, Canada: Canadian Industry Program for Energy Conservation.

Chaudhary, T. R. (2001). Technological measures of improving productivity: Opportunities and constraints. Presented at the Fertilizer Association of India Seminar "Fertiliser and Agriculture Future Directions," New Delhi, India, 6-8 December 2001.

Chidiak, M. (2000). Voluntary agreements-Implementation and efficiency. The French Country Study: Case studies in the sectors of packaging glass and aluminium. Paris: CERNA, Centre d'économie Industrielle, Ecole Nationale Supérieure des Mines de Paris.

Chidiak, M. (2002). Lessons from the French experience with voluntary agreements for greenhouse gas reduction. Journal of Cleaner Production, 10, 121-128.

Cornish, A. T., \& Kerkhoff, B. (2004). European standards and specifications in cements. In J. I. Bhatty, F. M. Miller, \& S. H. Kosmatka (Eds.), Innovations in Portland cement manufacture (pp. 1209-1218). Skokie: Portland Cement Association.

Dasgupta, M., \& Roy, J. (2000). Manufacturing energy use in India: A decomposition analysis. Asian Journal of Energy and Environment, 1, 223-247. 
De Beer, J. G., Harnisch, J., \& Kerssemeeckers, M. (2000a). Greenhouse gas emissions from iron and steel production. Cheltenham, UK: IEA Greenhouse Gas R\&D Programme.

De Beer, J. G., Kerssemeeckers, M. M. M., Aalbers, R. F. T., Vollebergh, H. R. J., Ossokina, J., de Groot, H. L. F., et al. (2000b). Effectiveness of energy subsidies: Research into the effectiveness of energy subsidies and fiscal facilities for the period 1988-1999. The Netherlands: Ecofys, Utrecht.

De Beer, J. G., Phylipsen, D., \& Bates, J. (2001). Economic evaluation of carbon dioxide and nitrous oxide emission reductions in industry in the EU. Belgium: European Commission-DG Environment, Brussels.

De la Rue du Can, S., \& Price, L. (2008). Sectoral trends in global energy use and greenhouse gas emissions. Energy Policy, 36(2008), 1386-1403.

De Keulenaer, H., Belmans, R., Blaustein, E., Chapman, D., De Almeida, A., \& De Wachter B. (2004). Energy efficient motor driven systems, <http://re.jrc.ec.europa.eu/ energyefficiency/pdf/HEM_lo_all\%20final.pdf $>$, accessed 01/06/07.

Delmas, M., \& Terlaak, A. (2000). Voluntary agreements for the environment: Innovation and transaction costs. CAVA Working Paper 00/02/13 February.

Dowd, J., Friedman, K., \& Boyd, G. (2001). How well do voluntary agreements and programs perform at improving industrial energy efficiency. Proceedings of the 2001 ACEEE Summer Study on Energy Efficiency in Industry. Washington, D.C.: American Council for an EnergyEfficient Economy.

EIA. (2005). Annual Energy Outlook 2005: With projections to 2025. Energy Information Agency, Washington, D.C., $<$ www.eia.doe.gov/oiaf/aeo/pdf/0383(2005).pdf>, accessed $31 / 05 / 07$.

Eidt, B. (2004). Cogeneration opportunities - Global Energy Management System. Presented at the 3rd API/DOE Conference on Voluntary Actions by the Oil and Gas Industry to Address Climate Change, September 29-30, 2004, Arlington, Virginia, <www.api.org/ehs/climate/response/upload/ 3rd_ConferenceSynopsis.pdf $>$, accessed 31/05/07.

Einstein, D., Worrell, E., \& Khrushch, M. (2001). Steam systems in industry: Energy use and energy efficiency improvement potentials. Proceedings of the 2001 ACEEE Summer Study on Energy Efficiency in Industry, 1, 535548 Tarrytown, NY, July 24-27th, 2001.

Farahani, S., Worrell, E., \& Bryntse, G. (2004). $\mathrm{CO}_{2}$-free paper? Resources and Conservation Recycling, 42, 317-336.

Farla, J., Blok, K., \& Schipper, L. (1997). Energy efficiency developments in the paper and pulp industry. Energy Policy, 25, 745-758.

Flannery, B. P. (2001). An industry perspective on carbon management. Presented at Carbon Management: Implications for R\&D in the Chemical Sciences and Technology, A Workshop Report to the Chemical Sciences Roundtable, (US) National Research Council.

Food and Agricultural Organization (FAO) (2008) Statistical database. $<$ http://faostat.fao.org/default.aspx>, accessed 9/06/08.

FPAC (n.d.) Environmental stewardship. Forest Products Association of Canada, <www.fpac.ca/en/sustainability/ stewardship $>$, accessed 31/05/07.

Future Energy Solutions (2004) Climate change agreements: Results of the second target period assessment, version
1.0. Didcot, UK: AEA Technology. www.defra.gov.uk/ environment/ccl/pdf/cca jul05.pdf

Future Energy Solutions. (2005). Climate change agreements: Results of the second target period assessment, Version 1.2. Didcot, UK: AEA Technology. <www.defra. gov.uk/environment/ccl/pdf/cca_aug04.pdf $>$, accessed 31/05/07.

George, G., \& Prabhu, G. N. (2003). Developmental financial institutions as technology policy instruments: Implications for innovation and entrepreneurship in emerging economies. Research Policy, 32, 89-108.

Grothcurth, H. M., Kummel, R., \& van Gool, W. (1989). Thermodynamic limits to energy optimization. Energy, 14, 241-258.

Hansen, K., \& Larsen, A. (1999). Energy efficiency in industry through voluntary agreements-The implementation of five voluntary agreement schemes and an assessment. Copenhagen: AKF, Amternes og Kommunernes Forskningsinstitut.

Heeres, R. R., et al. (2004). Eco-industrial park initiatives in the USA and the Netherlands: first lessons. Journal of Cleaner Production, 12(8-10), 985-995.

Hendriks, C. A., Worrell, E., Price, L., Martin, N., \& Ozawa Meida, L. (1999). The reduction of greenhouse gas emissions from the cement industry. Cheltenham, UK: IEA Greenhouse Gas R\&D Programme, Report PH3/7.

Humphreys, K., \& Mahasenan, M. (2002). Towards a sustainable cement industry-Substudy 8: Climate change. Geneva, Switzerland: World Business Council for Sustainable Development (WBCSD).

IEA. (1997). Voluntary actions for energy-related $\mathrm{CO}_{2}$ abatement. Paris: OECD/International Energy Agency.

IEA. (2007). $\mathrm{CO}_{2}$ emissions from fuel combustion (Edition 2007): 1971-2005. Paris: International Energy Agency.

IEA. (2008). World energy balances: 1971-2006 (Edition 2008). Paris: International Energy Agency.

IEA. (2005). R\&D Database. International Energy Agency, <www. iea.org/dbtw-wpd/textbase/stats/rd.asp $>$, accessed 31/05/07.

IEA. (2006a): Energy technology perspectives 2006: Scenarios and strategies to 2050. International Energy Agency, Paris, $484 \mathrm{pp}$.

IEA. (2006b). World energy outlook 2006 p. 596. Paris: International Energy Agency.

IEA-IETS. (n.d.). Implementing Agreement. International Energy Agency — Industrial Energy-Related Technology and Systems, <www.iea-iets.org>, accessed 31/05/07.

IFA. (2005). Summary report-World agriculture and fertilizer demand, global fertilizer supply and trade. International Fertilizer Industry Association 2005-2006. <www.fertilizer. org/ifa/publicat/PDF/2005_council_sevilla_ifa_summary. pdf $>$, accessed 31/05/07.

IPCC (2000). Emission scenarios. In N. Nakicenovic, et al. (Ed.), Special report of the Intergovernmental Panel on Climate Change (IPCC) (p. 598). Cambridge, UK: Cambridge University Press.

IPCC. (2001). Climate change 2001. In J. J. McCarthy, et al. (Eds.), Impacts, adaptation, and vulnerability. Intergovernmental Panel on Climate Change (IPCC) (167-299). Cambridge, UK: Cambridge University Press.

IPCC. (2007). Climate change 2007. In L. Bernstein, J. Roy et. al. (Eds.), Working Group III Report "Mitigation of Climate 
Change"; Chapter 7: Industry (pp. 447-496). Cambridge, UK: Cambridge University Press.

Kerssemeeckers, M. (2002). The Dutch long term voluntary agreements on energy efficiency improvement in industry. Utrecht, the Netherlands: Ecofys.

Kim, Y., \& Worrell, E. (2002a). International comparison of $\mathrm{CO}_{2}$ emissions trends in the iron and steel industry. Energy Policy, 30, 827-838.

Kim, Y., \& Worrell, E. (2002b). $\mathrm{CO}_{2}$ emission trends in the cement industry: An international comparison. Mitigation and Adaptation Strategies for Global Change, 7, 115-133.

Lemar, P. L. (2001). The potential impact of policies to promote combined heat and power in US industry. Energy Policy, $29,1243-1254$.

Luiten, E., \& Blok, K. (2003a). The success of a simple network in developing an innovative energy-efficient technology. Energy, 28, 361-391.

Luiten, E., \& Blok, K. (2003b). Stimulating R\&D of industrial energy-efficient technology; the effect of government intervention on the development of strip casting technology. Energy Policy, 31, 1339-1356.

Martin, N., Angliani, N., Einstein, D., Khrushch, M., Worrell, E., \& Price, L. (2000). Opportunities to improve energy efficiency and reduce greenhouse gas emissions in the $U$. $S$. pulp and paper industry. Berkeley, CA: Lawrence Berkeley National Laboratory, (LBNL 46141).

Matsuhashi, R., Shigyo, M., Yoshida, Y., \& Ishitani, H. (2000). Life cycle analysis of systems utilizing waste heat to reduce $\mathrm{CO}_{2}$ emissions. Proceedings of International Conference on Electrical Engineering, 613-616.

Miner, R., \& Lucier, A. (2004). A value chain assessment of the climate change and energy issues affecting the global forest products industry. <http://www.wbcsd.ch/web/ projects/forestry/ncasi.pdf>, accessed 01/06/07.

Nyboer, J., \& Tu, J. J. (2003). A review of energy consumption \& related data: Canadian cement manufacturing industry, 1990 to 2001: Canadian industry energy end-use data and analysis centre. Vancouver, BC: Simon Fraser University.

OECD. (2002). Voluntary approaches for environmental policy: Effectiveness, efficiency and use in policy mixes. Paris: Organization for Economic Cooperation and Development (OECD)

Okazaki, T., Nakamura, M., \& Kotani, K. (2004). Voluntary initiatives of Japan's steel industry against global warming. Paper presented at IPCC Industrial Expert Meeting (ITDT) in Tokyo.

Olivier, J. G. J., \& Peters, J. A. H. W. (2005). $\mathrm{CO}_{2}$ from nonenergy use of fuels: A global, regional and national perspective based on the IPCC Tier 1 approach. Resources, Conservation and Recycling, 45(3), 210-225.

Phylipsen, D., Blok, K., Worrell, E., \& De Beer, J. (2002). Benchmarking the energy efficiency of Dutch industry: an assessment of the expected effect on energy consumption and $\mathrm{CO}_{2}$ emissions. Energy Policy, 30, 663-679.

Phylipsen, G. J. M., \& Blok, K. (2002). The effectiveness of policies to reduce industrial greenhouse gas emissions. Paper for the AIXG Workshop on Policies to Reduce Greenhouse Gas Emissions in Industry-Successful Approaches and Lessons Learned, 2-3 December 2002, Berlin.
Price, L. (2005). Voluntary agreements for energy efficiency or GHG emissions reduction in industry: An assessment of programs around the world. Proceedings of the 2005 American Council for an Energy Efficient Economy Summer Study on Energy Efficiency in Industry, West Point, NY, USA, July, 2005.

Price, L., de la Rue du Can, S., Sinton, J., Worrell, E., Zhou, N., Sathaye, J., et al. (2006). Sectoral trends in global energy use and greenhouse gas emissions. Berkeley, CA: LBNL56144, Lawrence Berkeley National Laboratory.

PSI. (2004). Energy efficiency and $\mathrm{CO}_{2}$ emissions benchmarking of IFA Ammonia Plants (2002-2003 Operating Period). Plant Surveys International, Inc General Edition. Commissioned by the International Fertilizer Industry Association (IFA)

Rafiqul, I., Weber, C., Lehmann, B., \& Voss, A. (2005). Energy efficiency improvements in ammonia plants: Perspectives and uncertainties. Energy, 30, 2487-2504.

Ren, T., Patel, M., \& Blok, K. (2005). Natural gas and steam cracking: Energy use and production cost. Published in the conference proceedings of the American Institute of Chemical Engineers Spring National Meeting, Atlanta, GA, USA, 10-14 April, 2005.

Ren, T., Patel, M., \& Blok, K. (2006). Olefins from conventional and heavy feedstocks: Energy use in steam cracking and alternative processes. Energy, 31(4), 425-451.

Rietbergen, M. J., Farla, J. C. M., \& Blok, K. (2002). Do agreements enhance energy efficiency improvement? analyzing the actual outcome of the long-term agreements on industrial energy efficiency improvement in The Netherlands. Journal of Cleaner Production, 10, 153-163.

Sheinbaum, C., \& Ozawa, L. (1998). Energy use and $\mathrm{CO}_{2}$ emissions for Mexico's cement industry. Energy, 23, 725732.

Sinton, J. E., \& Fridley, D. G. (2000). What goes up: Recent trends in China's energy consumption. Energy Policy, 28, 671-687.

Starzer, O. (2000). Negotiated agreements in industry: Successful ways of implementation. Vienna, EVA: Austrian Energy Agency.

Swaminathan, B., \& Sukalac, K. E. (2004). Technology transfer and mitigation of climate change: The fertilizer industry perspective. Presented at the IPCC Expert Meeting on Industrial Technology Development, Transfer and Diffusion, Tokyo, Japan, 21-23 Sept. 2004.

United Nations (UN). (2007). United Nations Commodity Production Statistics. CD-ROM. United Nations.

UNFCCC. (2002). Good practices. Policies and measures among parties included in Annex I to the Convention in their Third National Communications-Report by the Secretariat. UN Framework Convention on Climate Change.

UNIDO. (2001). Africa industry and climate change project proceedings. UNIDO publication, Vienna: UN Industrial Development Organization.

US DOE. (2002). Steam system opportunity assessment for the pulp and paper, chemical manufacturing, and petroleum refining industries - main report. Washington, D.C.: US Department of Energy.

US EPA. (2006). Global anthropogenic emissions of non- $\mathrm{CO}_{2}$ greenhouse gas 1990-2020 (EPA Report 430-R-06-003). Washington, D.C., USA: United States Environmental Protection Agency Office of Air and Radiation. 
USGS. (2005). Minerals Yearbook 2004. US Geological Survey Reston, VA, USA. <http://minerals.usgs.gov/minerals/pubs/ myb.html >, accessed 31/05/07.

USGS. (2007). Minerals Yearbook 2006. US Geological Survey Reston, VA, USA. <http://minerals.usgs.gov/minerals/ pubs/myb.html $>$, accessed 31/05/07.

USGS. (2008). Minerals Yearbook 2006. US Geological Survey Reston, VA, USA. <http://minerals.usgs.gov/minerals/pubs/ myb.html>.

WBCSD. (2005). The cement sustainability initiative: Progress report. World Business Council for Sustainable Development, <www.wbcsdcement.org/pdf/csi_progress report_2005.pdf $>$, accessed 31/05/07.

WEC. (2001). Energy efficiency policies and indicators policies, World Energy Council London.

Worrell, E., \& Biermans, G. (2005). Move over! Stock turnover, retrofit and industrial energy efficiency. Energy Policy, 33, 949-962.

Worrell, E., \& Galitsky, C. (2004). Energy efficiency improvement opportunities for cement making-An ENERGY STAR Guide for Energy and Plant Managers. Berkeley, CA: Lawrence Berkeley National Laboratory, (LBNL 54036).
Worrell, E., \& Galitsky, C. (2005). Energy efficiency improvement opportunities for petroleum refineries-An ENERGY STAR Guide for Energy and Plant Managers. Berkeley, CA: Lawrence Berkeley National Laboratory (LBNL 56183).

Worrell, E., Smit, D., Phylipsen, K., Blok, K., van der Vleuten, F., \& Jansen, J. (1995). International comparison of energy efficiency improvement in the cement industry. Proceedings ACEEE 1995 Summer Study on Energy Efficiency in Industry, 2, 123-134.

Worrell, E., Price, L. K., Martin, N., Hendriks, C., \& Ozawa Meida, L. (2001). Carbon dioxide emissions from the global cement industry. Annual Review of Energy and Environment, 26, 303-329.

Worrell, E., Martin, N., Price, L., Ruth, M., Elliott, N., Shipley, A., et al. (2002). Emerging energy efficient technologies for industry. Energy Engineering Journal, 99, 36-55.

Worrell, E., Laitner, J. A., Ruth, M., \& Finman, H. (2003). Productivity benefits of industrial energy efficiency measures. Energy, 28, 1081-1098.

Xenergy, Inc. (1998) Evaluation of the US Department of Energy Motor Challenge Program. <www.eere.energy.gov/industry/ bestpractices/pdfs/mceval1_2.pdf $>$, accessed 31/05/07. 